\title{
The use of a flood index to characterise flooding in the north-eastern region of Bangladesh
}

\author{
B. Bhattacharya ${ }^{1, a}$, T. Islam² ${ }^{2}$, and S. Masud ${ }^{2}$, A. Suman ${ }^{3}$, and D.P. Solomatine \\ ${ }^{1}$ UNESCO-IHE Institute for Water Education, Westvest 7, 2601 DA Delft, The Netherlands \\ 2 Institute of Water Modelling, House \# 496, Road \# 32, New DOHS, Mohakhali, Dhaka, Bangladesh \\ ${ }^{3}$ Institute for Applied Ecology, Faculty of ESTeM, University of Canberra, Australia
}

\begin{abstract}
Flooding in the Haor region in the north-east of Bangladesh is presented in this paper. A haor is a saucershaped depression, which is used during the dry period (Dec to mid-May) for agriculture and as a fishery during the wet period (Jun-Nov). Pre-monsoon flooding till mid-May causes agricultural loss. The area is bordering India, and is fed by some flashy Indian catchments. The area is drained mainly by the Surma-Kushiyara river system. The terrain generally is flat and the flashy characteristics die out within a short distance from the border. Limited studies on the region, particularly with the help of numerical models, have been carried out in the past. Therefore, an objective of the current research was to set up numerical models capable of reasonably emulating the physical system. Such models could, for example, associate different gauges to the spatio-temporal variation of hydrodynamic variables and help in carrying out a systemic study on the flood propagation. A 1D2D model, with one-dimensional model for the rivers (based on MIKE 11 from DHI) and a two-dimensional model for the haors (based on MIKE 21 from DHI) were developed. In order to characterize flooding in the large area a flood index is proposed, which is computed based on the hydrograph characteristics such as the rising curve gradient, flood magnitude ratio and time to peak. The index was used in characterising flooding in the Haor region. In general, two groups of rivers were identified. The study enabled identifying the hot-spots in the study area with risks from flooding.
\end{abstract}

\section{Introduction}

Bangladesh is one of the largest deltas in the world, formed by a dense network of the distributaries of the rivers Ganges, Brahmaputra and Meghna, and more than 230 major rivers and their tributaries (Mirza, 2001). The Ganges, Brahmaputra and Meghna basin covers a combined total catchment area of about $1.76 \times 106 \mathrm{~km}^{2}$ and extends over Bangladesh, Bhutan, China, India and Nepal. Only $7 \%$ of this huge catchment area is in Bangladesh (Guna, 2002). The average annual rainfall in the country varies between 1500 to $5000 \mathrm{~mm}$ with an average of $2300 \mathrm{~mm}$. The geographical location, land characteristics, multiplicity of rivers and the monsoon climate render Bangladesh highly vulnerable to flood hazards. Floods are annual phenomena, with the most severe floods occurring during the months of July and August (Mirza, 2003).

Four main types of floods are observed in Bangladesh (Ahmed, 2000): flash flood, rainwater flood, riverine flood and coastal flood. Flash floods occur during the pre-monsoon period (March to May) and are observed in the north-eastern region due to intense rainfall events in the neighbouring hilly regions in India. Rain-fed flood is caused by drainage congestion and heavy rainfall. River floods result from snow-melt in the Himalaya region and heavy monsoon rainfall over the Himalayas, Assam Hills, Tripura Hills and the upper Brahmaputra and Ganges floodplains. Coastal flooding mostly occurs during the pre-monsoon and post-monsoon season. At this time, a number of depressions are formed in the Bay of Bengal, which often turn into cyclones that result in storm surges with a rapid onrush of water of high amplitudes in the coastal region.

Regular river floods affect $20 \%$ of the country, increasing up to $68 \%$ in extreme years (DMB, 2010). The floods of 1987, 1988, 1998 and 2004 were particularly catastrophic, resulting in large-scale destruction and loss of lives. Approximately $37 \%, 43 \%$, $52 \%$ and $68 \%$ of the country is inundated with floods of return periods of $10,20,50$ and 100 years respectively (DMB, 2010). The occurrence of water-induced disasters is a regular phenomenon in Bangladesh (Guna, 2002). The expression "living with floods" is used in a variety of contexts to illustrate the flooding situation in Bangladesh (Kundzewiez and Kaczmarek, 2000; Kundzewiez and Takeuehi, 1999). The flooding situation is anticipated to be exacerbated with the climate change. Most of the general circulation models (GCMs) predict an increase in temperature due to an enhanced greenhouse effect, which will increase monsoon precipitation in South Asia. This may lead to increase in peak discharges of the major

\footnotetext{
${ }^{\mathrm{a}}$ Corresponding author: B.Bhattacharya@unesco-ihe.org
} 
rivers and may eventually exacerbate the flooding problem in Bangladesh (Mirza, 2001).

This paper reports the research conducted in the framework of a project, which focused on the flooding issues in the Haor region in the north-east of Bangladesh. Section 2 introduces to the study area, Section 3 presents the set up of the simulation models, Section 4 introduces to flood index used subsequently in characterising flooding in the study area and Section 5 presents the results. The probable impact of climate change is discussed in Section 6.

\section{Study area}

Haors are almost round/elliptical shaped tectonically depressed and marshy lands. Haors are located mostly in the north-eastern region of Bangladesh covering an area of about $19700 \mathrm{~km}^{2}$ (CEGIS, 2011). There are about 411 haors in that region with about 23 trans-boundary rivers that enter Bangladesh (CEGIS, 2011). Due to the intense rainfall at the upper catchment area and hilly topography, the rivers carry floodwater quickly to downstream, which leads to flooding in the Haor region. The upstream catchments in India receive heavy rainfall and include world's highest rainfall occurring location Cherapunjee. The Haor region is drained mainly by the SurmaKushiyara river system. The area is bordering India, thereby presenting trans-boundary issues as well, and is fed by some flashy Indian catchments. The terrain generally is flat and the flashy characteristics die out within a short distance from the border.

During the dry period (Dec to mid-May) a haor is used for agriculture and during the wet period (Jun-Nov) it is used as a fishery. Pre-monsoon flooding till midMay causes agricultural loss and lot of distress whereas monsoon flooding brings benefits. Boro rice is the main crop of the region. The pre-monsoon flooding, which occurs during April and May is a major proponent of risk to the economic, social and environmental sectors in the Haor region (IWM, 2007). Pre-monsoon flooding can cause loss of crops of the entire year. Most haors are protected with embankments created by the Bangladesh Water Development Board (BWDB). The purpose of the embankments is to protect haor's crop from pre-monsoon floods. The embankments are of low heights, which can protect the area for minor floods but not major floods (IWM, 2007). During monsoon most of the embankments become inundated. This is why these embankments of that area are called submergible embankment. Repeated floods over the last few years have also weakened the existing embankments and poor maintenance causes breaching during flooding. Since last several years the region also uses a high-yield variety of rice crop, which has slightly delayed the harvesting time, and as a result has increased the flood risk.

\section{Setting up of models}

Due to the complex nature of the river systems in the Haor area and their hydrological/ hydraulic characteristics, characterisation of floods and planning and designing mitigation measures are quite difficult. To see the spatial and temporal extent of flooding in rivers and flood plains (Haors) it was considered necessary to develop a 1D-2D model. Under the present study rivers were modelled with a 1D model and haors were modelled with a $2 \mathrm{D}$ model. The $1 \mathrm{D}$ model was used to study the water level and discharge in the main river while the 1D2D model was used to measure the depth and extent of flood in the haors. The hydrodynamic simulation engine underneath was based upon the complete Saint Venant Equations.

The 1D model was developed with MIKE-11. Available gauge data was used in providing the upstream boundary data for all the rivers connected to the area. Water level obtained from the gauge station at upper Meghna was used as the downstream boundary condition. A 2D model was developed with MIKE-21 modelling system. The available DEM was created using the satellite data (SRTM) of $90 \mathrm{~m}$ by $90 \mathrm{~m}$ resolution. In order to be able to represent the embankments, which have tiny widths, two types of computational mesh were developed for using in the 2D model. Rectangular mesh was developed for embankments around the periphery of each haor and triangular flexible mesh was developed for the rest of the Haor area.

MIKE-Flood model was developed by integrating the $1 \mathrm{D}$ and 2D models. Twelve rivers were laterally linked by 36 reaches and 489 points. The $1 \mathrm{D}$ model was calibrated with respect to the water level gauge observation in Surma River. The 2004 flood was used for the calibration.

While the 1D model was calibrated well the calibration of the $2 \mathrm{D}$ model was an issue due to the nonavailability of measured data. The flood extent of the 2D model was calibrated to a limited extent with the remote sensing images. The flood extent simulated by the 2D model was compared with the flood extent from the satellite image SATIS on 15 May 2004 (CEGIS, 2011). However, it was not possible to ascertain the depth of flood from the satellite image. So the $2 \mathrm{D}$ model was compared to only the flood extent of satellite images. From the analysis of the satellite image and model results on the same date at the Haor area, it was concluded that the flood extent simulated by the model was close to the flood extent depicted on the satellite imagery. However, the $2 \mathrm{D}$ model needs further experiments on calibration and will be taken up later.

\section{Flood index}

We followed the approach of Bhaskar et al. (2000) and Ahn and Choi (2013) to express the severity of flooding by flood index (FI), which is computed based on some specific characteristics past flood hydrographs. In particular, we noticed that three characteristics of flood hydrographs were used for computing FI (Ahn and Choi, 2013; Bhaskar et al., 2000). These characteristics are flood magnitude ratio, rising curve gradient and time to peak, and are explained below. 


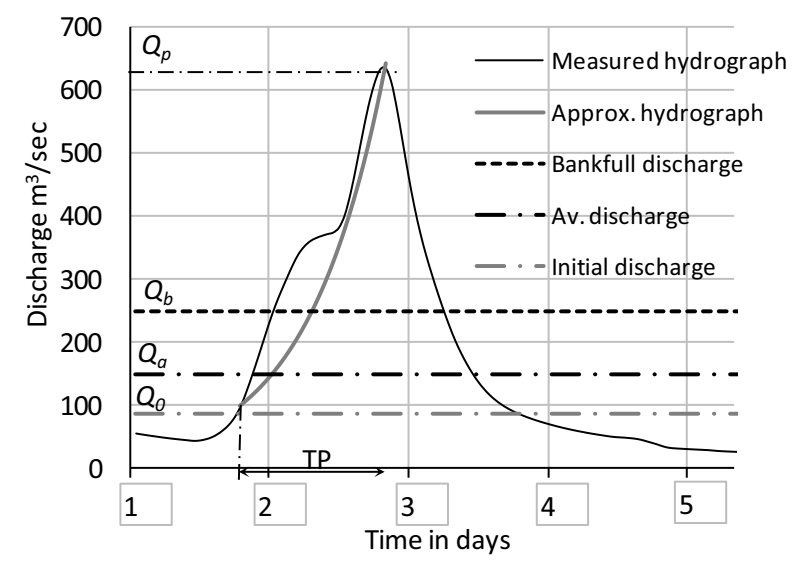

Figure 1. A measured flood hydrograph (in Baulal River in October 2004) along with its approximated version with the flood index parameters.

The flood magnitude ratio $(M)$ is defined as the ratio of the peak flood $\left(Q_{p}\right)$ to the long-term average discharge $\left(Q_{a}\right)$ and is expressed as:

$$
M=Q_{p} / Q_{a}
$$

The rising curve gradient $(K)$ is related to the steepness of the rising limb of the hydrograph and is expressed as:

$$
Q_{t}=Q_{0} e^{K t}
$$

Where $Q_{t}$ is the flood discharge at time $t, Q_{p}$ is the flood peak, $Q_{0}$ is the initial discharge and $K$ is the rising curve gradient (day-1).

The parameter time to peak $(T P)$ is expressed as the time in hours between the starting time of flooding $\left(T_{0}\right)$ and the time the peak flood occurs $(T p)$ :

$$
T P=T_{p}-T_{0}
$$

The computed parameters need to be normalised. Some researchers (e.g. Ahn and Choi, 2013) have suggested normalising the parameters with respect to the largest value of the computed parameters. We propose to use the 100-year flood in normalising the parameters. The procedure is explained below:

$$
\begin{aligned}
& M_{n}=M / M_{100} \\
& K_{n}=K / K_{100} \\
& T P_{n}=T P_{100} / T P
\end{aligned}
$$

Where $M_{n}, K_{n}$ and $T P_{n}$ are the normalised values of $M, K$ and $T P . M_{100}, K_{100}$ and $T P_{100}$ refer to the $M, K$ and $T P$ values of the 100 -year flood.

If the 100-year flood is not known then it can be estimated using other mechanisms (e.g. regionalisation method). If estimating the 100-year flood is difficult then as an alternative the maximum observed flood in the catchment may be used in the normalisation procedure. The FI can be computed as the geometric mean of the normalised parameters:

$$
F I=\sqrt[3]{\left(M_{n}\right)\left(K_{n}\right)\left(T P_{n}\right)}
$$

Note that a prime advantage of the approach is in identifying severity of a flood in relation to a standard flood (100-year flood). By computing FI at different locations of the catchment a spatial variation of FI can be computed, and therefore, FI can be used in identifying risk locations. If a flood frequency study is available then FI can be computed for any flood magnitude with its known hazard probability. The spatial and temporal variation of FI provides a synoptic view of the variation of risk from flooding in the catchment and as a result can be useful in flood risk management.

\section{Characterisation of flooding}

The analysis of the model results showed the existence of two types of rivers in the region: quick response and slow response rivers. In quick response rivers the time to reach the flood peak was about 2 days, which for the slow response rivers was about 10 days.

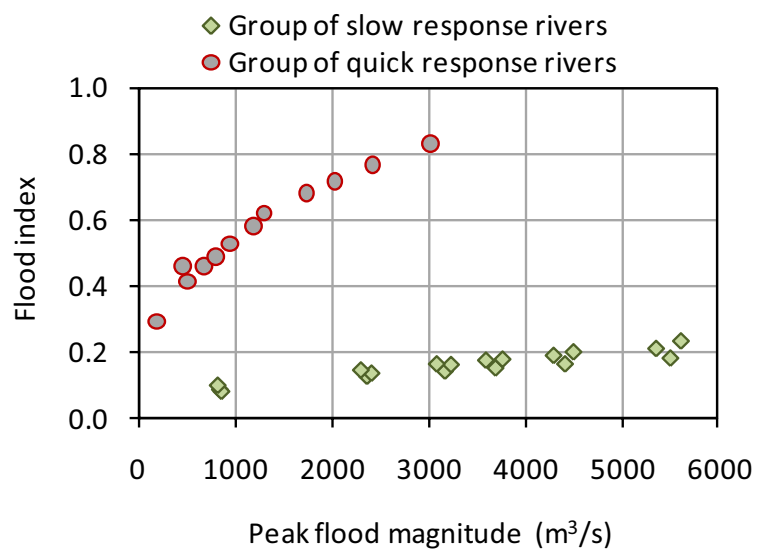

Figure 2. Variation of flood indices with peak flood discharge in the Haor region.

Among the different rivers of the region the Nawa River was observed to be a slow response river. Its average flood response time was about 11 days. Flood frequency analysis showed that the flood of 2004 in the Nawa River $\left(5009 \mathrm{~m}^{3} / \mathrm{s}\right)$ was close to the flood of 100 year return period. The Baulal River, on the other hand, was observed to be a quick response river of the region. Its average flood response time was about two days.

The FI values for 24 flood events in the Haor region were computed. The computed parameters and the FI values corresponding to four chosen floods are shown in Fig. 3. Subsequently, we computed the temporal variation of the FI values for the Haor region. As FI was calculated from flood hydrograph so, it should change with flood of different return periods. By carrying out a flood frequency analysis of the Haor region flood magnitudes of different return periods for each of the rivers were computed. For each river and for varying flood magnitudes the FI values were computed using Eq. (1) to (7) (Fig. 4). The spatial and temporal variation of FI of the catchment provides a synoptic view of the flooding characteristics of the Haor region. 


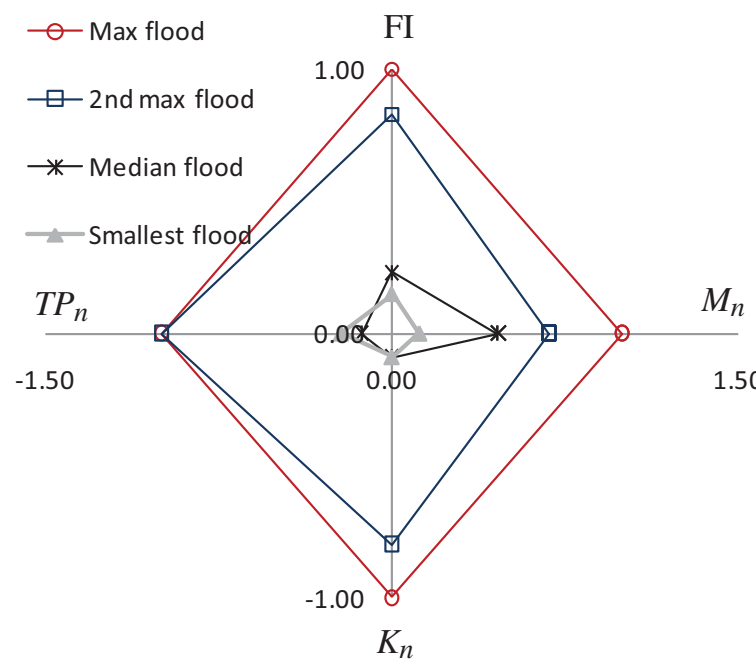

Figure 3. Flood indexing parameters for four floods in the Haor region as per the presented approach.

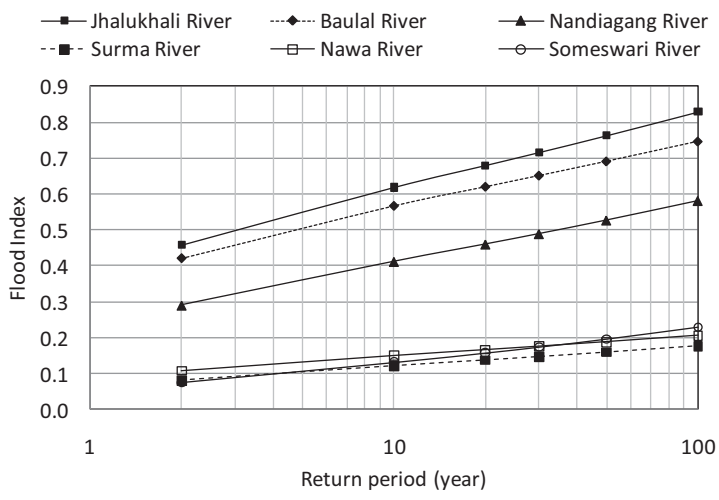

Figure 4. Temporal variation of flood index in different rivers of the Haor region for different return periods.

\section{Impact of climate change}

South Asia perhaps is one of the most vulnerable regions of the world to climate change impacts. The international community also recognizes that Bangladesh ranks high on the list of most vulnerable countries. Bangladesh's high vulnerability to climate change is due to a number of hydro-geological and socio-economic factors (Ahmed, 2006). Similar to the other regions of Bangladesh, the Haor region, is also likely to be affected by the climate change. During pre-monsoon and monsoon periods an increase in the precipitation is anticipated and subsequently an increase in the volume of surface runoff may aggravate the flooding condition in the area. Due to climate change induced inundation, a large portion of the area could face major challenges in terms of displaced populations and their loss of income (CEGIS, 2011).

Table 1 shows the likely changes in precipitation in 2050 and 2090 based on two scenarios considered in the IPCC report. The following three different global circulation models were considered: CSIRO-Mk3.5,
ECHam5 and MIROC3.2(medres). Lal and Aggarwal (2001) simulated daily rainfall in the CCSR/NIES A-O GCM corresponding to the year 2050. The analysis suggests an intensification of the monsoon rainfall over the Indian subcontinent and an enhancement in the summer monsoon precipitation variability in each of the four SRES marker emission scenarios. They also examined the frequency distribution of daily monsoon rainfall over India and suggested that the intensity of extreme rainfall events is likely to be higher in future, a consequence of increased convective activity during the summer.

Table 1. Percentage increase in precipitation according to the B1 and A2 scenarios with different global circulation models.

\begin{tabular}{|l|c|c|c|c|}
\hline \multirow{2}{*}{ GCM model } & \multicolumn{2}{l|}{$\begin{array}{l}\text { \% of } \\
\text { precipitation } \\
\text { increase in } \\
\text { Scenario (B1) }\end{array}$} & \multicolumn{2}{l|}{$\begin{array}{l}\text { \% of } \\
\text { precipitation } \\
\text { increase in } \\
\text { Scenario (A2) }\end{array}$} \\
\cline { 2 - 5 } & 2050 & 2090 & 2050 & 2090 \\
\hline CSIRO-Mk3.5 & 5.31 & 6.60 & 8.35 & 16.42 \\
\hline ECHam5 & 2.76 & 11.75 & 3.46 & 17.82 \\
\hline MIROC3.2(medres) & 9.99 & 15.77 & 11.96 & 19.28 \\
\hline
\end{tabular}

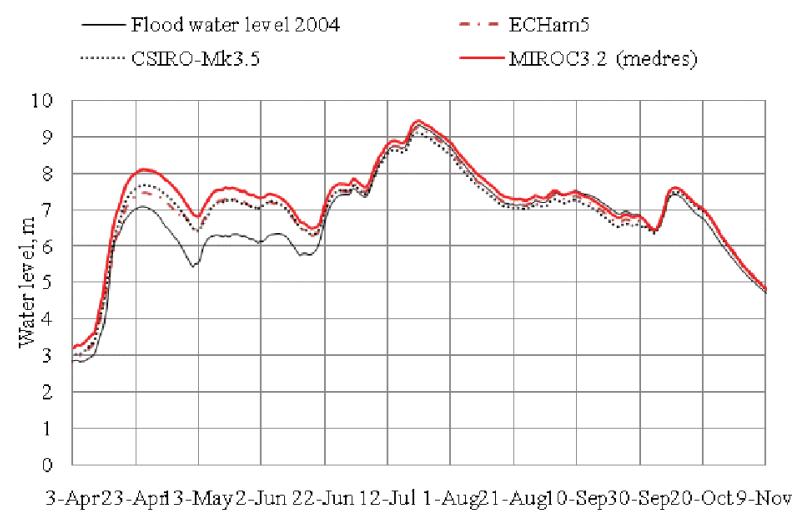

Figure 5. Changes in the simulated water level corresponding to climate change.

In the present study, corresponding to the changes suggested in Table 1, new simulations of the study area was carried out. Both scenarios (A2 and B1) and three GCMs were considered. Initial simulation results corresponding to all the GCMs indicate an increase in flood water level corresponding to the same flood, although the degree of variations was different (Fig 5). The climate change impact assessment results are only preliminary results and require further studies.

\section{Conclusions}

The paper presents the flood characteristics of the Haor area of Bangladesh and the potential impact of climate change in the region. The analysis was carried out by developing a $1 \mathrm{D}$ model for the rivers and $2 \mathrm{D}$ model for the haors using the 2004 flood data. The results 
showed that there are mainly two categories of rivers in the study area. The first group belong to slow response rivers with time to reach the peak about 10 days. The second group refers to quick response rivers with the time to reach the peak is about 2 days.

The paper further presents computation of flood index, which has been developed by modifying the existing approaches. The flood index was used in analysing the flooding risk in the Haor region. The spatial and temporal variation of the index in the catchment provides a synoptic view of the flooding characteristics of the Haor region.

The possible impact of climate change on flood severity in the region was assessed with three GCMs: ECham5, CSIRO-Mk3.5 and MIROC3.2 (medres). The IPCC scenarios B1 and A2 were considered. All GCMs predict an increase in precipitation in the Haor region. Initial results of the assessment of climate change impact show that flood severity of the slow response rivers will increase significantly compared to the quick response rivers.

\section{Acknowledgement}

Part of this work was performed in the framework of the project MorphoFlood of the DGIS UNESCO-IHE Programmatic Cooperation supported by the Dutch government.

\section{References}

1. Ahmed, A.U. (2000). Review of causes and dimensions of floods with particular reference to Flood '98: national perspectives. pp. 67-84. Dhaka University Press Limited, Dhaka.

2. Ahmed, A.U. (2006). Bangladesh climate change impacts and vulnerability, a synthesis. Climate Change Cell, Dept. of Env., Comprehensive Disaster Management Programme, Bangladesh.

3. Ahn J.H., Choi H. Il. (2013). A new flood index for use in evaluation of local flood severity: A case study of small ungauged catchments in Korea 1. J. Am. Water Resour. Assoc. 49:1-14.

4. Bhaskar, N.R., French, M.N., and Kyiamah G.K. (2000). Characterization of flash floods in eastern Kentucky. J. Hydrol. Eng. 5:327-331.

5. CEGIS (2011). Master Plan of the Haor area. Bangladesh Haor and Wetland Development Board, Ministry of Water Resources, Bangladesh.

6. DMB (2010). National plan for disaster management 2010-2015. Disaster Management Bureau, Disaster Management \& Relief Division, Bangladesh.

7. Guna, N, P. (2002). Forecasting and warning of water-related disasters in a complex hydraulic setting - the case of Bangladesh. Hydrological Sci. J., 47:S1, S5-S18.

8. IWM (2007). Mathematical modelling along with hydrological studies \& terrestrial survey under the Haor rehabilitation scheme. Final report, Institute of Water Modelling, Bangladesh.
9. Kundzewiez, Z.W. and Kaczmarek, Z. (2000). Coping with hydrological extremes. Water International. 25(1), 66-75.

10. Kundzewiez, Z.W. and Takeuehi, K. (1999). Flood protection and management. Hydrological Sci. J. 44(3), 417- 432.

11. Lal, M. and Aggarwal, D. (2001). Climate change and its impacts on India. Asia Pacific Journal on Environment and Development. 7 (1), 1-41.

12. Mirza, M.M.Q. (2001). Global warming and changes in the probability of occurrence of floods in Bangladesh and implications. Global Environmental Change. 12, 127-138.

13. Mirza, M.M.Q. (2003). Three recent extreme floods in Bangladesh: a hydro meteorological analysis. Natural Hazards, 28, 35-64. 